\title{
Correction to: Aerodynamic analysis of uphill drafting in cycling
}

\author{
T. van Druenen ${ }^{1}$ (D) B. Blocken ${ }^{1,2}$ (D)
}

Published online: 14 June 2021

(c) International Sports Engineering Association 2021

\section{Correction to: Sports Engineering (2021) 24:10 \\ https://doi.org/10.1007/s12283-021-00345-2}

In the original publication, the third sentence in Introduction section was published incorrectly. The correct sentence should read as "There appear to be no systematic and extensive studies on the aerodynamics of uphill drafting in the literature."

The original article has been corrected.

Publisher's Note Springer Nature remains neutral with regard to jurisdictional claims in published maps and institutional affiliations.

The original article can be found online at https://doi.org/10.1007/ s12283-021-00345-2.

T. van Druenen

t.v.druenen@tue.nl

1 Building Physics and Services, Department of the Built Environment, Eindhoven University of Technology, PO Box 513, 5600 MB Eindhoven, The Netherlands

2 Building Physics and Sustainable Design, Department of Civil Engineering, KU Leuven, Kasteelpark Arenberg 40, Bus 2447, 3001 Heverlee, Belgium 